\title{
37. DOMINANT STRUCTURAL TRENDS ON THE WESTERN CONTINENTAL MARGIN OF IBERIA: IMPLICATIONS ON INITIAL RIFTING ${ }^{1}$
}

\author{
Jean-Claude Sibuet, Centre Océanologique de Bretagne, Brest, France \\ and \\ Léopold Berthois, 6 rue de Viarmes, 35000 Rennes, France
}

\section{INTRODUCTION}

Preparatory to IPOD site surveys for Leg 47B, a provisional bathymetric map was established (three sheets, scaled 1:500,000) for the area west of the Iberian peninsula. This report presents a new version of this bathymetric map (scaled $1: 2,400,000$ at $41^{\circ} \mathrm{N}$ ) which incorporates data obtained since 1974 .

\section{ORIGIN OF DATA}

Bathymetric contours on the continental shelf were drawn using numerous soundings of the Service Hydrographique et Océanographique de la Marine Française (map numbers 3388 [1959], 6088 [1963], 6133 [1956], 6229 [1963], and 6611 [1974]), and of the Instituto Hidrographico de Portugal (map numbers 1 [1970], 2 [1973], 4 [1970], 5 [1971], 6 [1972], and 7 [1973], compiled at a 1:150,000 mean scale). Complementary data from other sources concerning the continental shelf are scanty.

Several deep-ocean data sources were employed, as follows:

1) Unpublished bathymetric maps drawn by Berthois et al. (1965) from unpublished data of the Institut Scientifique des Pêches Maritimes, obtained by the R/V Président Théodore Tissier and Thalassa during their 1956 to 1964 cruises.

$\begin{array}{cc}\text { Sheet Number } & \text { Scale } \\ 13 & 1: 231,500 \\ 14 & 1: 236,600 \\ 15 & 1: 242,100 \\ 16 & 1: 247,000\end{array}$

2) Carte bathymétrique du golfe de Gascogne at a scale of $1: 500,000$ at $46^{\circ} \mathrm{N}, \mathrm{CNEXO}$ Sheets $74-4$ and 74-5 by Berthois (1974).

3) Bathymetric map of the Museum d'Histoire Naturelle, Laboratoire d'Océanographie Physique: Du Détroit de Gibraltar au Cap Saint-Vincent, unpublished map, 1971.

4) GEBCO bathymetric soundings at a 1:1,000,000 scale, plotting Sheets $42,43,59$, and 60 .

5) Bathymetry of the northeast Atlantic, Sheet 3: Mid-Atlantic Ridge to southwest Europe by Laughton et al. (1975) of the Institute of Oceanographic Sciences, United Kingdom, at a scale of $1: 2,400,000$ at $41^{\circ} \mathrm{N}$.

\footnotetext{
'Contribution 582 of the Scientific Department of the Centre Océanologique de Bretagne.
}

6) Sounding sheets from the Service Hydrographique et Océanographique de la Marine Français F/V d'Entrecasteaux at a $1: 1,000,000$ scale at $46^{\circ} \mathrm{N}$ (1973).

Bathymetric soundings from campagne Noratlante, R/V Jean Charcot, 3 August-2 November 1969. Publication du Centre National pour l'Exploitation des Océans (CNEXO). Série Résultats des campagnes a la mer, number 1,385 pages (1971).

8) Unpublished data from the following cruises: (a) R/V Jean Charcot, Cruist CH01, Centre Océanologique de Bretagne (1969); (b) R/V Jean Charcot, Cruise GIBRACO, $\mathrm{CH} 29$ and $\mathrm{CH} 30$, Centre Océanologique de Bretagne (1972); (c) R/V Jean Charcot, Cruise CINECA IV, $\mathrm{CH} 61$ and $\mathrm{CH} 62$, Centre Océanologique de Bretagne (1973); (d) R/V Jean Charcot, Cruise GEOBRESIL, $\mathrm{CH} 49$, Centre Océanologique de Bretagne (1973); (e) R/V Jean Charcot, Cruise ALBATLANTE, CH 56 and 57, Centre Océanologique de Bretagne (1974); (f) R/V Noroit, Cruises N 11 and N 12, Centre Océanologique de Bretagne and Université Pierre et Marie Curie (1975); (g) R/V Jean Charcot, Cruise CH 80, Université Pierre et Marie Curie (1976); and (h) R/V Jean Charcot, transit using the Sea-Beam equipment (1977).

\section{PRODUCTION OF MAPS}

Soundings are expressed in corrected meters using Matthew's (1939) tables. Contours were drawn at a scale of 1:500,000 with an isobath spacing of 200 meters. Unpublished profiles listed above are shown in dashed lines with or without documented soundings. The nomenclature of submarine features is from Laughton et al. (1975). The three original maps (Figures 1, 2, and 3) have been photographically reduced to a $1: 2,400,000$ scale at $41^{\circ} \mathrm{N}$ (i.e., to the scale of Laughton et al. [1975]). Maps at a 1:500,000 scale are available from the Centre Océanologique de Bretagne.

\section{TECTONIC SETTING OF THE WEST IBERIAN CONTINENTAL MARGIN}

The main bathymetric features of the northeast Atlantic have been described by Laughton et al. (1975). Thus, we focus on the morphology of the continental margin west of Iberia in the area of Site 398. The western continental margin of Iberia is a rifted-type margin (e.g., Bott, 1976; Le Pichon et al., 1977) created during several tensional episodes since the Early Permian between Iberia and North America (Groupe 


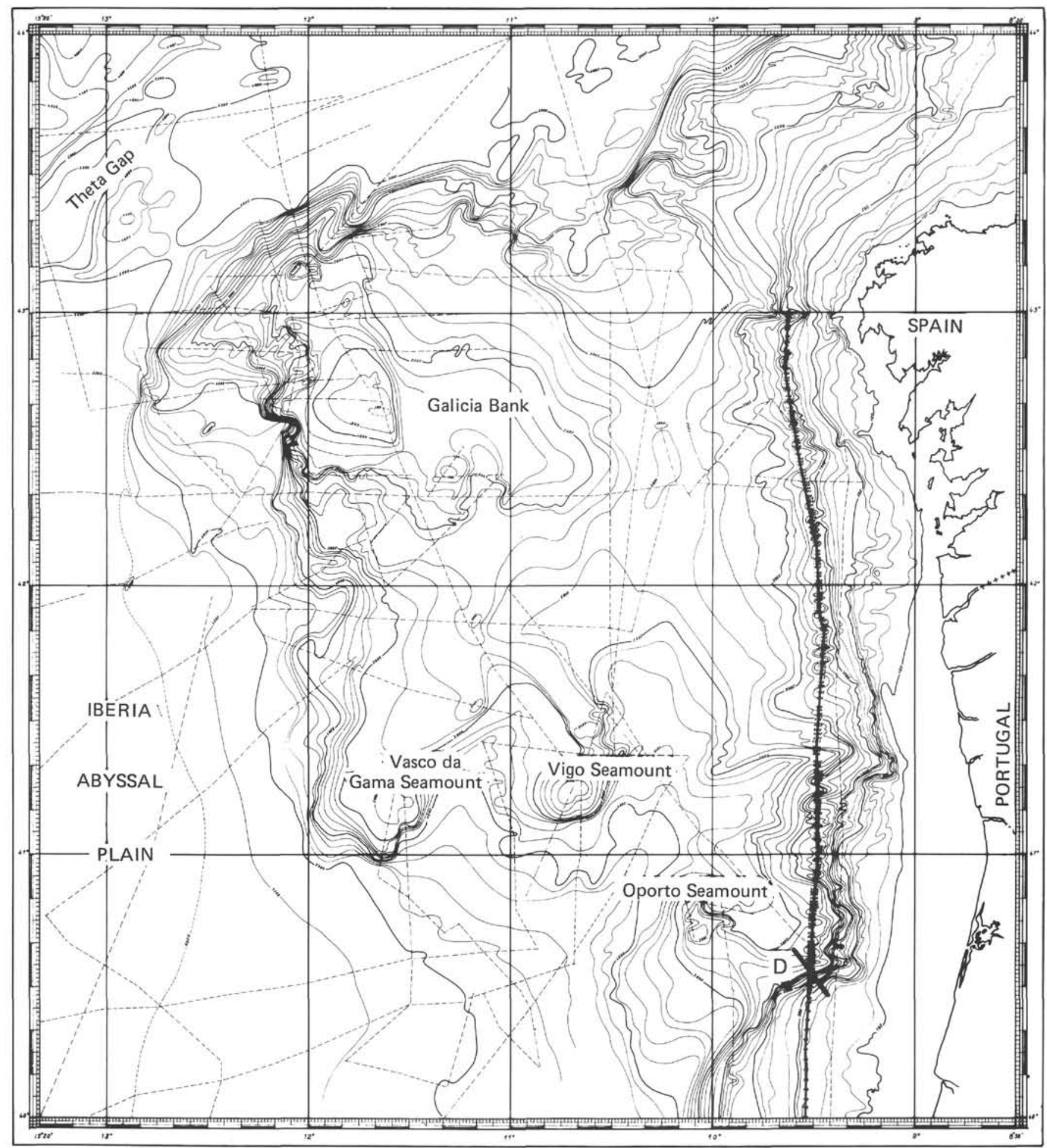

Figure 1. Bathymetric map west of Iberia (Sheet 1) in corrected meters (Matthews, 1939). Scale of 1:2,400,000 at 41 ${ }^{\circ}$. Isobath spacing $=200$ meters. Unpublished tracklines in dashed lines (see text). Nomenclature of submarine features from Laughton et al. (1975).

Galice; Sibuet and Ryan; both, this volume). Nevertheless, the general morphology of this margin, at least in the vicinity of Site 398, was formed in Early Cretaceous time (late Barremian to latest Aptian) during a tensional episode responsible for the horst and half- graben structures (Sibuet and Ryan, this volume). Also, the regional morphology of this margin is largely controlled by the late Hercynian fracturing pattern. The São Vincente, Setubal, Lisboa, and Nazaré canyons roughly follow the late Hercynian shear directions 


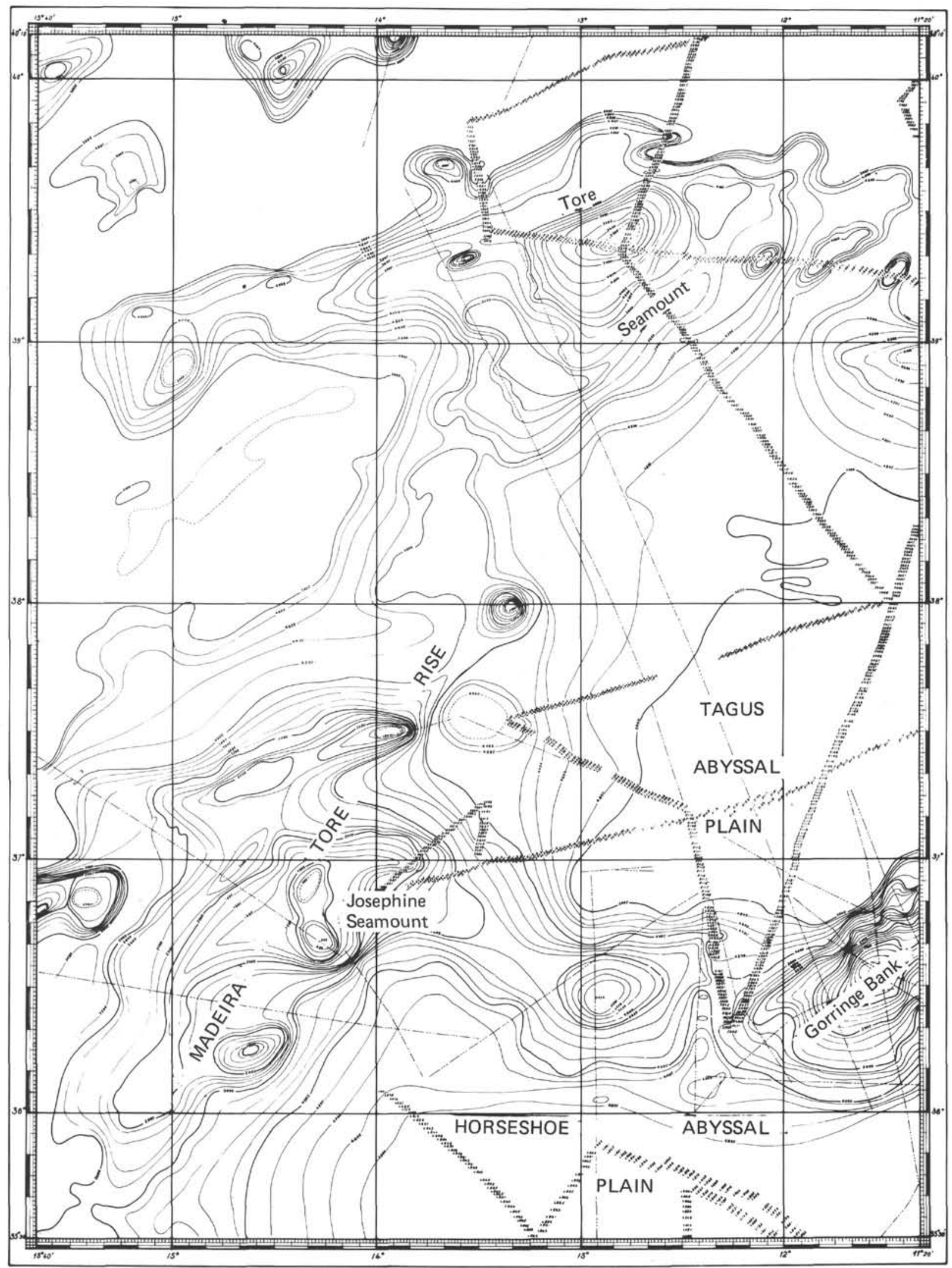

Figure 2. Bathymetric map west of Iberia (Sheet 2). 


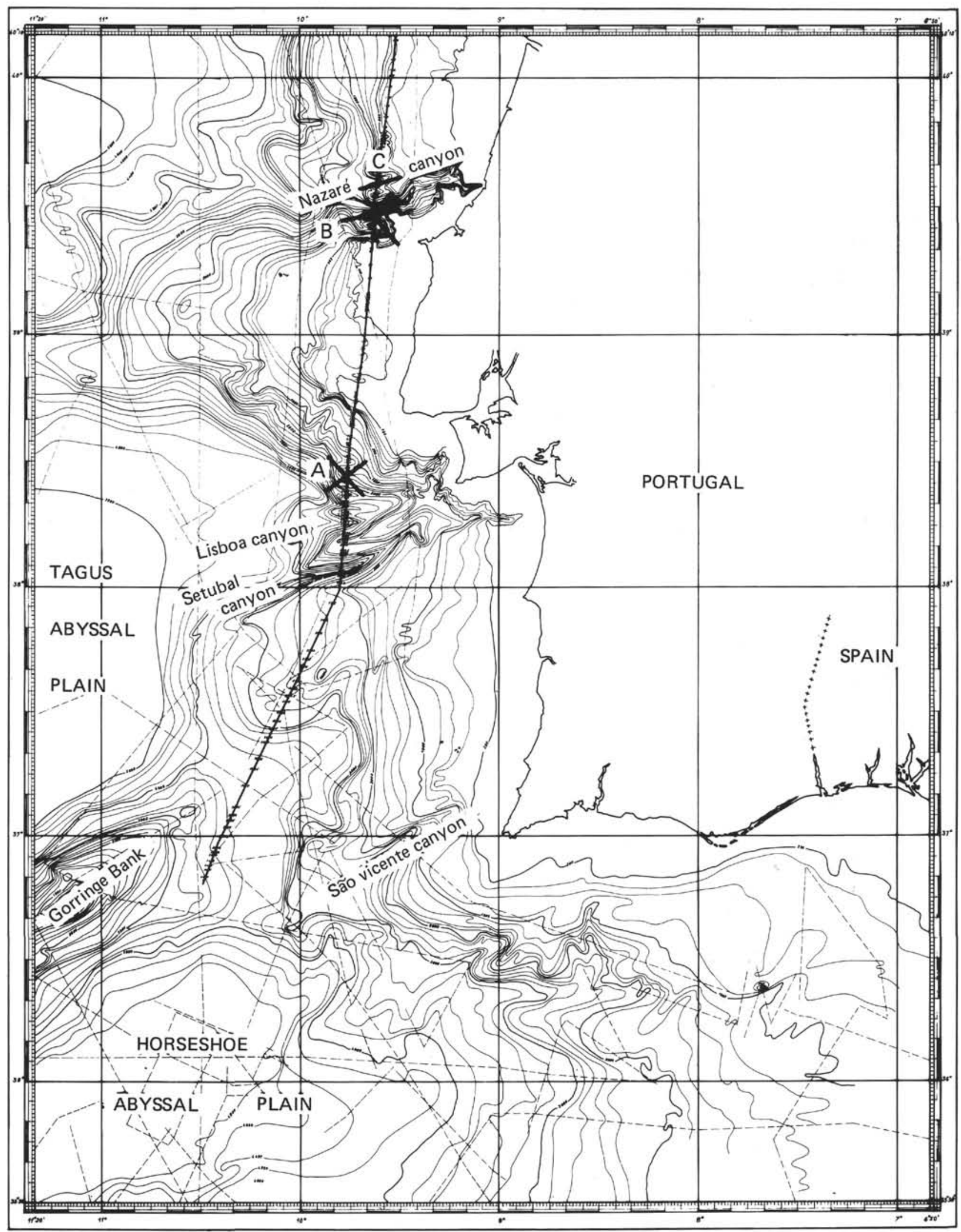

Figure 3. Bathymetric map west of Iberia (Sheet 3). 
(E-ENE) as pointed out by several authors (Berthois et al., 1965; Boillot et al., 1974).

Previous studies suggest that Galicia Bank and the Vigo, Oporto, and Vasco da Gama seamounts are subsided continental blocks (Black et al., 1974; Pautot et al., 1970; Montadert et al., 1974) and were also affected by the late Hercynian pattern of faults (Groupe Galice, this volume). These features, approximately at the same depth (except for Galicia Bank), could have been affected by Late Cretaceous-early Tertiary compressive movements which affected the northern margin of Iberia (Sibuet and Le Pichon, 1971; Boillot et al., 1971; Le Pichon and Sibuet, 1971). These features probably have subsided continuously from the sea level since latest Aptian times, which marked the beginning of continuous sea-floor spreading west of Iberia (Sibuet and Ryan, this volume; Sibuet et al., in press).

A multibeam echo-sounder profile on the western Iberian continental margin was obtained in December of 1977 with depths generally between the 1000- and 2000-meter isobaths (Figures 1 and 3). The multibeam echo-sounder built by the General Instrument Corporation is sold under the name of "Sea-Beam." It consists of 15 narrow beams, the output of which is processed in real time. Contour maps are plotted at a chosen scale. The width of the real time contour plot is approximately $3 / 4$ of the water-depth (Renard; Renard and Allenou; Allenou and Renard; all in press). One of the most important advantages of this system is that morphological trends are directly outlined on records (Figure 4).

Several authors (Le Pichon and Hayes, 1971; Sibuet and Mascle, 1978) consider that the break-up of continents must have occurred along previous zones of weakness which had affected the whole lithosphere. To test this hypothesis, trend directions have been calculated on the sea-beam profile. Linear features used in this study are valleys of canyons when they are narrow and of constant width (Figures $4 \mathrm{~A}$ and $\mathrm{B}$ ), walls of canyons when valleys are widened out, and external limits of spurs. Sixty-two directions have been measured from $37.5^{\circ}$ to $43^{\circ} \mathrm{N}$ (Figures 1 and 3). The frequency distribution of these directions has been obtained with averages over $10^{\circ}$. Two main peaks $\left(45^{\circ} \mathrm{N}\right.$ and $\left.71^{\circ} \mathrm{N}\right)$ and three smaller ones $\left(97^{\circ} \mathrm{N}, 314^{\circ} \mathrm{N}\right.$, and $\left.335^{\circ} \mathrm{N}\right)$ appear in Figure 5. The error in the determinations, about $10^{\circ}$, results largely from the bathymetric profile having been run in very rough sea conditions (waves 7 to $8 \mathrm{~m}$ high).

Arthaud and Matte (1975) have demonstrated that late Hercynian strike-slip faulting in the Iberian peninsula, resulting from a north-south to northwestsoutheast compression, occurred along three main directions, i.e., northeast-north-northeast, northwestnorth-northwest, and east-east-northeast. These wrench faults with offsets of a few kilometers to several hundred kilometers, were active from middle Carboniferous (Westphalian, $300 \pm 10$ m.y.) to Early Permian (280 m.y.). Their directions on the photogeologic map (IFPCNEXO maps, 1976; Biju-Duval et al., 1976) correspond to a well-developed pattern of faults. In the western part of Iberia, the mean directions of these trends have been calculated using about 40 measurements for each type of fault. The directions obtained are $37^{\circ} \mathrm{N}, 73^{\circ} \mathrm{N}$, and $311^{\circ} \mathrm{N}$ with a quadratic error of $5^{\circ}$ to $6^{\circ}$ (Figure 5 ).

The main implication of Figure 5 is that the northeast-north-northeast, northwest-north-northwest, and east-east-northeast maxima in directions over Iberia, which are respectively $37^{\circ} \pm 6^{\circ}, 311^{\circ} \pm 6^{\circ}$, and $73^{\circ} \pm 5^{\circ}$ (determinations on the photogeologic map), overlap with the $45^{\circ} \pm 10^{\circ}, 314 \pm 10^{\circ}$, and $71^{\circ} \pm 10^{\circ}$ maxima in trend directions (Figure 5) measured on the margin which represent 70 per cent of the measured events. Consequently, the morphology of this margin seems to be controlled by the late Hercynian fracture pattern as pointed out by several authors (Berthois et al., 1965; Le Pichon et al., 1971; Boillot et al., 1974). This new well-defined correspondence between late Hercynian trends on land and on the continental margin westwards of Iberia clearly demonstrates that the initial break-up of continents between Iberia and North America has been guided by the previously acquired fault pattern. The initiation of the break-up of continents in this area is consequently post-late Hercynian (middle Carboniferous; Westphalian, $300 \pm 10$ m.y.) to Early Permian ( 280 m.y.) fracturing as recognized by most authors (e.g., Le Pichon et al., 1977; Groupe Galice, this volume). We suggest that the dominance of the $45^{\circ} \mathrm{N}$ and $71^{\circ} \mathrm{N}$ directions on the continental margin, which reflect a similar dominance on the continent, may indicate that the initial motion of North America with respect to Iberia could have followed this northeast-east-northeast strike slip direction, the conjugate direction being a direction of readjustment associated with rifted segments of the continental margin.

\section{ACKNOWLEDGMENTS}

The data used in this paper were gathered during numerous cruises. We wish to thank scientists, officers, and crews aboard $\mathrm{CNEXO}$ research vessels for their assistance in gathering the data. The manuscript was critically reviewed by $\mathrm{X}$. Le Pichon and L. Montadert.

\section{REFERENCES}

Allenou, J. P. and Renard, V., in press. Le Sea-Beam, sondeur a faisceaux multiples du Jean-Charcot, Notice technique, Comptes-Rendus Scientifiques et Techniques du CNEXO, v. 37.

Arthaud, F. and Matte, P., 1975. Les décrochements TardiHercyniens du Sud-Ouest de l'Europe. Géométrie et essai de reconstitution des conditions de la déformation, Tectonophysics, v. 25, p. 139-171.

Berthois, L., Brenot, R., and Ailloud, P., 1965. Essai d'interprétation morphologique et géologique de la pente continentale à l'Ouest de la péninsule ibérique, Rev. Trav. Inst. Pêches mar., v. 29, p. 343-350.

Biju-Duval, B., Lamerein, C., and Rivereau, J., 1976. Commentaire de l'esquisse photogéologique du domaine méditerranéen, Rev. Inst. Français du Pétrole, v. 31, p. 365-400.

Black, M., Hill, M. N., Laughton, A. S., and Matthews, D. H., 1964. Three non-magnetic seamounts off the Iberian coast, Quat. J. of the Geol. Soc. of London, v. 120, p. $477-517$. 

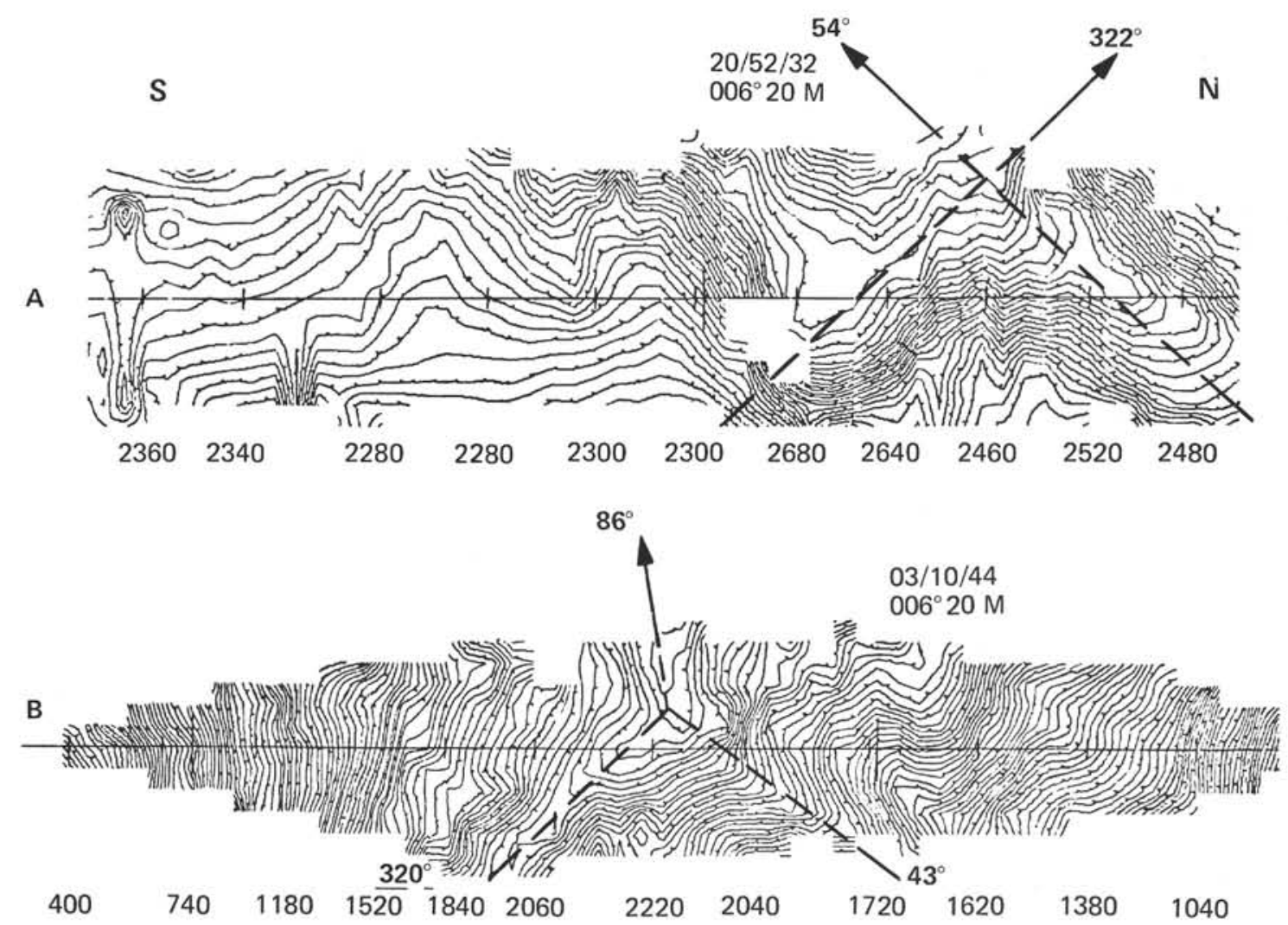

c
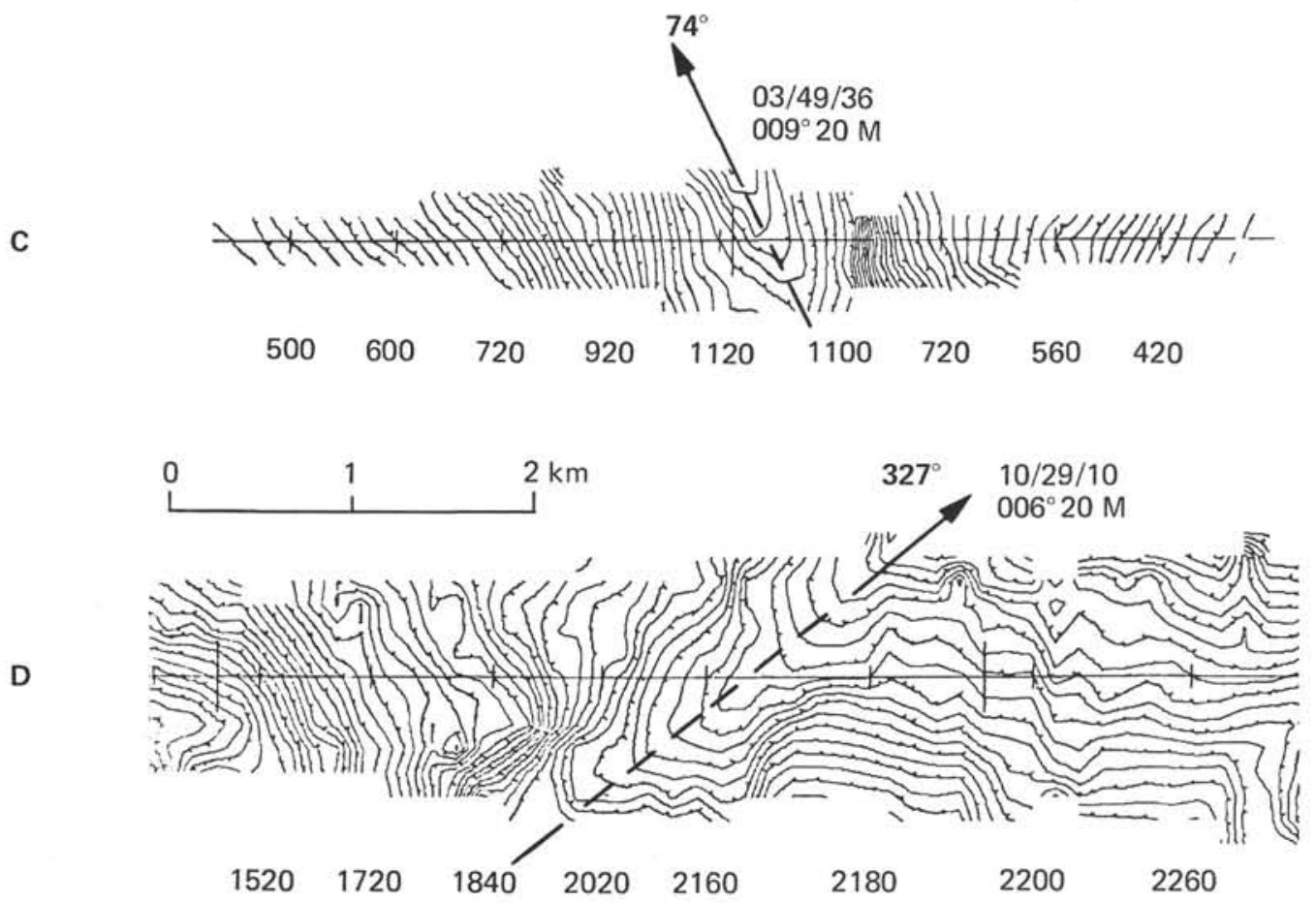

Figure 4. Real-time bathymetric contour maps. The horizontal central lines represent the ship's track. Large lines cutting across this line correspond to the time (hour, minute, second), the course, and the contouring interval. Small lines cutting across both the main line and isobaths correspond to the depth written below. Small ticks along isobaths are on the deepest side. The original scale was 1:25,000; after reduction, the scale is 1:50,000. Four examples of canyons are shown and located in Figures 1 and 3. Orientations of canyons are indicated. Note that canyons follow conjugate structural directions (Figures $4 A$ and $B$ ) and that a change in the trend of a canyon is shown in $4 B$. 


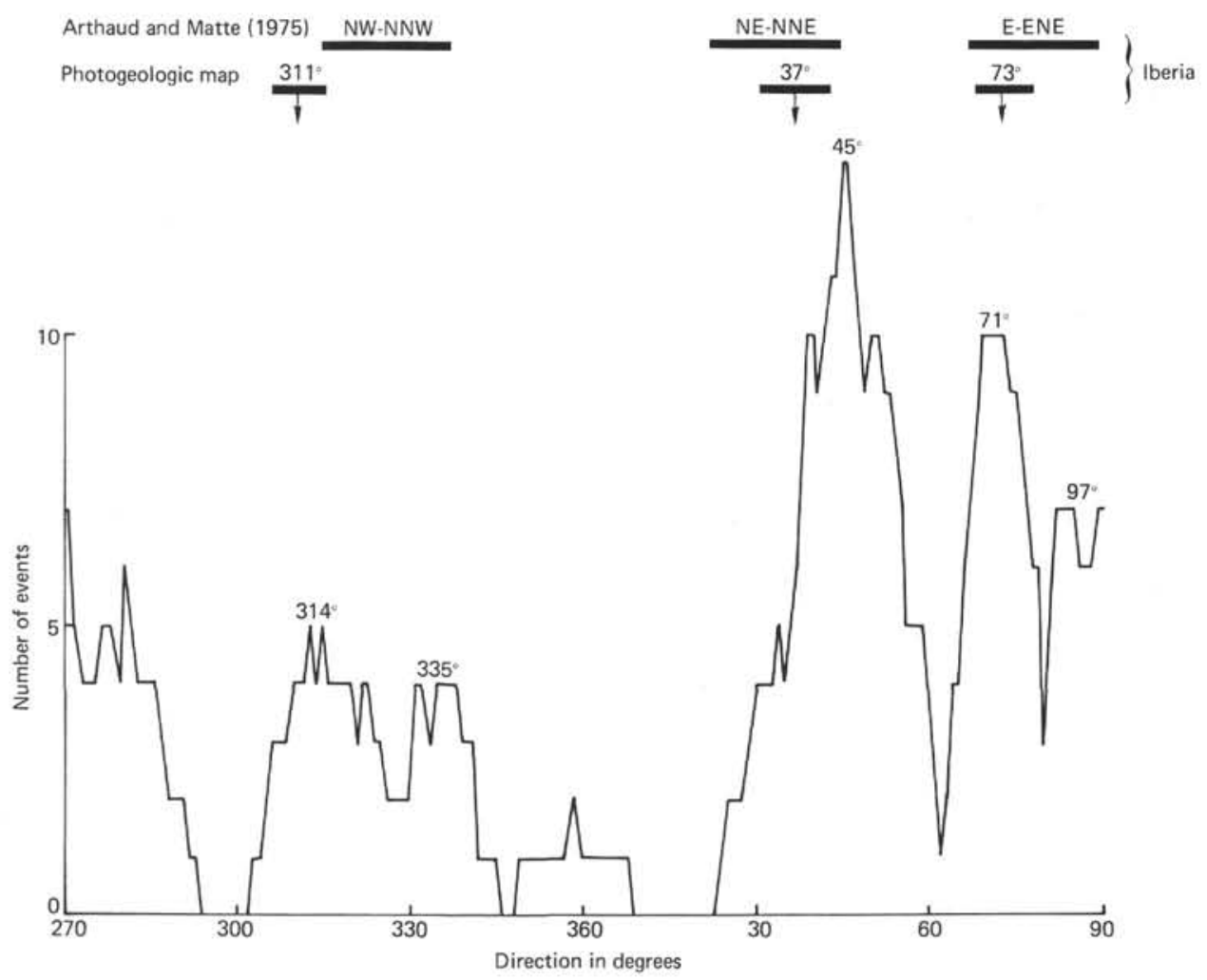

Figure 5. Frequency distribution of trends on the western Iberian continental margin using averages over $10^{\circ}$. Late Hercynian fracture directions in Iberia from Arthaud and Matte (1975) and from the photogeologic map (IFP-CNEXO Sheet 1, 1976).

Boillot, G., Dupeuble, P. A., Lamboy, M., D'Ozouville, L., and Sibuet, J. C., 1971. Structure et histoire géologique de la marge continentale au nord de l'Espagne (entre $4^{\circ}$ et $9^{\circ}$ W). In Debyser, J., et al. (Eds.), Histoire structurale du Golfe de Gascogne: Paris (Technip), v. 6, p. 1-52.

Boillot, G., Dupeuble, P. A., Hennequin-Marchand, I., Lamboy, M., Leprêtre, J. P., and Musellec, P., 1974. Le rôle des décrochements "Tardi-Hercyniens" dans l'évolution structurale de la marge continentale et dans la localisation des grands canyons sous-marins à l'Ouest et au Nord de la péninsule ibérique, Rev. de Géographie Phys. et de Géol. Dyn., v. 16, p. 75-86.

Bott, M.H.P., 1976. Problems of the formation and geodynamic development of Atlantic-type continental margins, Anais da Academia Brasileira de Ciencas, v. 48, p. 37-42.

Institut Français du Pétrole and Centre National pour l'Exploitation des Océans (IFP-CNEXO), 1976. Esquisse photogéologique du domaine méditerranéen. Grands traits structuraux à partir des images de satellite Landsat 1 . Portugal-Espagne-Maroc-Algérie (Marge Atlantique-Mer d'Alboran), Sheet 1 . Scale $1: 2,500,000$ at $40^{\circ} \mathrm{N}$ latitude: Paris (Technip).

Instituto Hidrografico de Portugal. Missao hidrografica da Costa de Portugal, maps no. 1 to 7, Mercator projection, scale of 1:150,000. Soundings in meters.

Laughton, A. S., Roberts, D. G., and Graves, R., 1975. Bathymetry of the northeast Atlantic: Mid-Atlantic Ridge to southwest Europe, Deep-Sea Research, v. 22, p. 791-810.

Le Pichon, X. and Sibuet, J. C., 1971. Western extension of boundary between European and Iberian plates during the Pyrenean orogeny, Earth and Planet. Sci. Lett., v. 12, p. 83-88.
Le Pichon, X., Bonnin, J., Francheteau, J., and Sibuet, J. C., 1971. Une hypothèse d'évolution tectonique du Golfe de Gascogne. In Debyser, J., et al. (Eds.), Histoire structurale du Golfe de Gascogne: Paris (Technip), v. 6, p. 1-44.

Le Pichon, X. and Hayes, D. E., 1971. Marginal offsets fracture zones, and the early opening of the South Atlantic, J. Geophys. Res., v. 76, p. 6283-6293.

Le Pichon, X., Sibuet, J. C., and Francheteau, J., 1977. The fit of the continent around the North Atlantic ocean, Tectonophysics, v. 38, p. 169-209.

Matthews, D. J., 1939. Tables of the velocity of sound in pure water and sea water, Hydrographic Department, Admiralty, HD 282.

Montadert, L., Winnock, E., Delteil, J. R., and Grau, G., 1974. Continental margins of Galicia-Portugal and Bay of Biscay. In Burk, C. A. and Drake, C. L. (Eds.), The Geology of continental margins: New York (Springer-Verlag), p. 323-342.

Pautot, G., Auzende, J. M., and Le Pichon, X., 1970. Continuous deep sea salt layer along north Atlantic margins related to early phase of rifting, Nature, v. 227, p. 351-354.

Renard, V., in press. Le Jean Charcot: premier navire océanographique équipé d'un sondeur bathymétrique à faisceaux étroits multiples Sea-Beam, Revue Navigation.

Renard, V. and Allenou, J. P., in press. Le Sea-Beam, sondeur à multi-faisceaux du N/O Jean Charcot, description et premiers résultats, Revue Hydrographique Internationale.

Service Hydrographique et Océanographique de la Marine Française (E.P.S.H.O.M. Brest France) maps no. 3388, $6088,6133,6229$, and 6611. Mercator projection. Soundings in meters. 
Sibuet, J. C. and Le Pichon, X., 1971. Structure gravimétrique du Golfe de Gascogne et le fossé marginal nord-espagnol. In Debyser, J. et al. (Eds.), Histoire Structurale du Golfe de Gascogne: Paris (Technip), v. IV, 9, p. 1-17.

Sibuet, J. C. and Mascle, J., 1978. Plate kinematic implications of Atlantic equatorial fracture zones, J. Geophys. Res., v. 83 , p. $3401-3421$.
Sibuet, J. C., Ryan, W.B.F., Arthur, M., Barnes, R., Blechsmidt, G., De Charpal, O., de Graciansky, P. C., Habib, D., Iaccarino, S., Johnson, D., Lopatin, B. G., Maldonado, A., Montadert, L., Moore, D. G., Morgan, G. E., Mountain, G., Rehault, J. P., Sigal, J., and Williams, C. A., in press. Deep drilling results of Leg 47B (Galicia Bank area) in the framework of the early evolution of the North Atlantic Ocean, Phil. Trans. Roy. Soc. London. 